\title{
Effects of body condition, monensin, and essential oils on ruminal lipopolysaccharide concentration, inflammatory markers, and endoplasmatic reticulum stress of transition dairy cows
}

\author{
C. Drong, ${ }^{*}$ S. Bühler, ${ }^{* 1}$ J. Frahm, ${ }^{*}$ L. Hüther, ${ }^{*}$ U. Meyer, ${ }^{*}$ D. von Soosten, ${ }^{*}$ D. K. Gessner, $†$ K. Eder,† \\ H. Sauerwein, $\ddagger$ and S. Dänicke* \\ *Institute of Animal Nutrition, Friedrich-Loeffler-Institut (FLI), Federal Research Institute for Animal Health, Bundesallee 50, 38116 Braunschweig, \\ Germany \\ †Institute of Animal Nutrition and Nutrition Physiology, Justus-Liebig-Universität Giessen, Heinrich-Buff-Ring 26-32, 35392 Giessen, Germany \\ łInstitute of Animal Science, Physiology and Hygiene Unit, University of Bonn, Katzenburgweg 7-9, 53115 Bonn, Germany
}

\section{ABSTRACT}

Evidence exists that dairy cows experience inflammatory-like phenomena in the transition period. Rumen health and alterations in metabolic processes and gene networks in the liver as the central metabolic organ might be key factors for cows' health and productivity in early lactation. This study made use of an animal model to generate experimental groups with different manifestations of postpartal fat mobilization and ketogenesis. In total, 60 German Holstein cows were allocated 6 wk antepartum to 3 high-body condition score (BCS) groups (BCS 3.95) and 1 low-BCS group (LC; BCS 2.77). High-BCS cows were fed an antepartal forage-to-concentrate ratio of 40:60 on dry matter basis, in contrast to 80:20 in the LC group, and received a monensin controlled-release capsule (HC/MO), a blend of essential oils ( $\mathrm{HC} / \mathrm{EO})$, or formed a control group (HC). We evaluated serum haptoglobin, kynurenine, tryptophan, ruminal lipopolysaccharide concentration and mRNA abundance of nuclear factor kappa B (NF$\kappa \mathrm{B})$, nuclear factor E2-related factor 2 (Nrf2), and endoplasmatic reticulum stress-induced unfolded protein response (UPR) target genes in liver biopsy samples from d -42 until +56 relative to calving. Nearly all parameters were highly dependent on time, with greatest variation near calving. The ruminal lipopolysaccharide concentration and evaluated target genes were not generally influenced by antepartal BCS and feeding management. The kynurenine-to-tryptophan ratio was higher in LC than in $\mathrm{HC} / \mathrm{MO}$ treatment on $\mathrm{d} 7$. Ruminal lipopolysaccharide concentration was higher in $\mathrm{HC} / \mathrm{MO}$ than in the $\mathrm{HC}$ group, but not increased in $\mathrm{HC} / \mathrm{EO}$ group. Abundance of UPR target gene Xbox binding protein 1 was higher in $\mathrm{HC} / \mathrm{MO}$ than in

Received August 3, 2016.

Accepted December 21, 2016.

${ }^{1}$ Corresponding author: Susanne.Buehler@fli.de
HC/EO group on d 7. Hepatic mRNA abundance of Nrf2 target gene glutathione peroxidase 3 was higher, whereas expression of NF- $\kappa \mathrm{B}$ target gene haptoglobin tended to be higher in LC than in $\mathrm{HC} / \mathrm{EO}$ cows. The $\mathrm{HC} / \mathrm{MO}$ cows showed the most prominent increase in the abundance of glutathione peroxidase 3 and haptoglobin after calving in comparison to antepartal values. Results indicate the presence of inflammatory-like phenomena near calving. Simultaneously, alterations in UPR and Nrf2 target genes with antioxidative properties and haptoglobin occurred, being most prominent in $\mathrm{LC}$ and HC/MO group.

Key words: monensin, essential oils, inflammation, endoplasmatic reticulum stress

\section{INTRODUCTION}

In the transition period, the dairy cow is confronted with a massive change in the metabolic status. The increasing nutrient and energy demands cannot be met by feed intake and lead to a mobilization of body tissues (Grummer, 1995). Excessive release of fatty acids exceeds the liver's metabolic capacity and is associated with hepatic diseases such as fatty liver or ketosis (Duffield, 2000; Bobe et al., 2004). Besides metabolic stress, the cow is exposed to inflammatory challenges in early lactation (Bertoni et al., 2008; Trevisi et al., 2012; Bradford et al., 2015). Evidence exists that inflammatory-like phenomena also occur within the liver tissue, where an acute phase response is induced by proinflammatory cytokines (Bionaz et al., 2007; Gessner et al., 2013; Bradford et al., 2015). Their release can be triggered by infectious challenges, trauma, metabolic disorders (Trey and Kushner, 1995), and also by increased ruminal accumulation and translocation of bacterial LPS into the circulation due to the feeding management and the potential occurrence of SARA around calving (Gozho et al., 2007; Penner et al., 2007; Zebeli et al., 2015). 
Metabolic and oxidative stress, proinflammatory cytokines, and microbial components such as LPS are potential stimuli for the induction of endoplasmatic reticulum (ER) stress (Ringseis et al., 2015). The ER stress is defined as an imbalance between the folding capacity of the ER and the protein load, resulting in an accumulation of unfolded or misfolded proteins in the ER lumen (Cnop et al., 2012). In turn, this induces an adaptive response, called the unfolded protein response (UPR), that aims at restoring ER homeostasis and, if not possible, can lead to the induction of apoptosis (Fu et al., 2012). Among others, it leads to an activation of the nuclear factor E2-related factor 2 (Nrf2) transcription factor, upregulating antioxidant and cytoprotective enzymes (Cullinan and Diehl, 2004) and the initiation of inflammation (Zhang and Kaufmann, 2008). Recent literature indicates that ER stress might be etiologically involved in the development of fatty liver in humans, and evidence has shown that it might also be a main contributing factor to liver-associated diseases of the cow (Zhang et al., 2014; Ringseis et al., 2015). In accordance, it was actually shown that genes of the ER stress-induced UPR and several target genes of Nrf2 were increased in early-lactating dairy cows (Gessner et al., 2013; Gessner et al., 2014).

Monensin belongs to ionophore antimicrobial drugs and is known for its selective action against grampositive bacteria, which lead to a change in the ruminal fermentation pattern (Russell and Strobel, 1989). Our preceding examinations indicated that a monensin controlled-release capsule (CRC) increases the ruminal propionate production, reduces the prevalence of either subclinical or clinical ketosis (BHB $>1.2 \mathrm{mmol} / \mathrm{L}$ ) by $53 \%$, improves the postpartal hepatocyte integrity, and generates the highest antibody scores after a antepartal bovine viral diarrhea virus vaccination in high-body condition cows (Drong et al., 2016a,b). Furthermore, monensin was shown to modify the acute phase response (Stephenson et al., 1997; Crawford et al., 2005). Essential oils present a dietary alternative to the pharmaceutical monensin, as they were also shown to modulate ruminal fermentation; additionally, evidence suggests that they possess antibacterial, antioxidative, and anti-inflammatory properties (Edris, 2007).

As an animal model was applied that makes use of different manifestations of the factors BCS (Edmonson et al., 1989) and concentrate (forage-to-concentrate ratio $=80: 20$ vs. 40:60) antepartum and a decelerated energy supply postpartum (Schulz et al., 2014), one purpose of the current study was to determine the effects of these 2 factors on postpartal ruminal LPS concentration. As an increased translocation of ruminal LPS into circulation might be a contributing factor to the extent of inflammatory-like phenomena in early- lactating cows, we evaluated selected inflammatory markers in blood and the mRNA abundance of several inflammatory, UPR, and Nrf2 target genes in liver biopsy samples of these dairy cows during the transition period. We hypothesized that a modulation of the ruminal fermentation via promoting gram-negative bacteria by monensin and essential oils is accompanied by an increase in free ruminal LPS, as it is part of the bacterial outer membrane (Rietschel et al., 1994). The main objective of our study was to examine if this effect also influences the postpartal inflammatory state of the high-body condition cows.

\section{MATERIALS AND METHODS}

\section{Experimental Design}

The experiment was conducted at the experimental station of the Institute of Animal Nutrition, FriedrichLoeffler-Institut Braunschweig, in accordance with the Animal Welfare Act concerning the protection of experimental animals with the approval of the Lower Saxony State Office for Consumer Protection and Food Safety (LAVES, file no. 33.14-42502-04-11/0444, Oldenburg, Germany). The animals were housed in freestall barns and milked twice daily at 0530 and $1530 \mathrm{~h}$.

The outline of the whole experiment is described in full detail by Drong et al. (2016a). In brief, 60 multiparous German Holstein cows (parity $2.3 \pm 1.4$; mean \pm SD) were allocated $42 \mathrm{~d}$ antepartum to either a high BCS group $(n=45)$, with a BCS of $3.95 \pm 0.08$, or to low BCS group $(\mathbf{L C} ; \mathrm{n}=15$, parity $1.7 \pm 0.9)$, with a BCS of $2.77 \pm 0.14$. Further criteria were the milk yield and composition of the previous lactation, BW, and parity. All included cows were healthy, irrespective of prior diseases. The high BCS group was subdivided into 1 control group $(\mathbf{H C} ; \mathrm{n}=15$, parity $2.5 \pm 1.4)$ and 2 groups receiving either monensin $(\mathbf{H C} / \mathbf{M O} ; \mathrm{n}=15$, parity $2.6 \pm 1.3$ ) or essential oils $(\mathbf{H C} / \mathbf{E O} ; \mathrm{n}=15$, parity $2.4 \pm 1.6$ ) from $d-21$ until 56 DIM.

The chemical composition of the pre- and postpartal experimental diet is presented in Table 1 . The ingredients and chemical composition of the roughages and concentrates are shown in detail by Drong et al. (2016a). In the dry period, LC cows were fed according to the recommendations of the German Society of Nutrition Physiology (GfE, 2001), with an energetic adequate ration of $80 \%$ roughage ( $50 \%$ maize silage, $50 \%$ grass silage) and 20\% concentrate based on DM content. The high-BCS groups received an energetic oversupply through an increased concentrate feed proportion of $60 \%$ of the daily ration. After calving, all cows were fed a TMR adjusted for lactation requirement with an initial concentrate feed proportion of $30 \%$; this ratio 
was raised stepwise to $50 \%$ of the daily ration. This increase was decelerated ( 3 vs. 2 wk) in the highBCS groups to stimulate postpartal lipolysis (Schulz et al., 2014). The TMR was provided ad libitum via self-feeding stations (type RIC, Insentec B.V., Marknesse, the Netherlands). In addition, concentrate was provided by a computerized concentrate feeding station (Insentec B.V.). The HC/EO treatment included a blend of essential oils (Crina Ruminants, DSM, Basel, Switzerland) in the pelleted concentrate, with the target to provide $1 \mathrm{~g}$ of essential oils/cow per day from $\mathrm{d}$ $-21(-22 \pm 7)$ antepartum, whereas the other groups received a control concentrate. The product contains a patented mixture of natural and synthesized essential oils compounds including thymol, eugenol, vanillin, guaiacol, and limonene (McIntosh et al., 2003). The $\mathrm{HC} / \mathrm{MO}$ group received a monensin CRC (Kexxtone, Elanco, Bad Homburg, Germany) orally at d -21 ( -19 \pm 5 ) before calving, which steadily released $335 \mathrm{mg}$ of monensin/d for a period of $95 \mathrm{~d}$.

\section{Measurements and Sample Collection}

The study started at $\mathrm{d}-38 \pm 6$ (range $\mathrm{d}-53$ to $-29)$ relative to calving in the $\mathrm{LC}$ group, at $\mathrm{d}-38 \pm$ 8 (range $\mathrm{d}-49$ to -25 ) in thte $\mathrm{HC}$ group, at $\mathrm{d}-41$ \pm 6 (range $\mathrm{d}-54$ to -33 ) in the $\mathrm{HC} / \mathrm{MO}$ group, and at $\mathrm{d}-41 \pm 9$ (range $\mathrm{d}-53$ to -25 ) in the $\mathrm{HC} / \mathrm{EO}$ group. Of the 12 blood sampling points in the present trial (Drong et al., 2016a), blood samples from d -42 $(-40 \pm 7$; range $d-54$ to -25$),-3(-2 \pm 1$; range $d$ -8 to -1$),+1,+7,+21$, and $\mathrm{d}+56$ relative to calving taken from the jugular vein were used for the determination of the haptoglobin, tryptophan, and kynurenine concentration. After centrifugation $\left(2,000 \times g, 15^{\circ} \mathrm{C}\right.$, $15 \mathrm{~min}$ ) of the serum tubes (Heraeus Varifuge, 3.0R; Heraeus Instruments, Osterode, Germany), serum was stored at $-80^{\circ} \mathrm{C}$ until analysis.

Samples of rumen fluid were taken from 4 cows of each group after blood sampling by using an oral rumen tube and a hand vacuum pump from the ventral sac of the rumen on $\mathrm{d} 7,14,21,35$, and 56 relative to calving. After centrifugation (Heraeus Varifuge; 10,000 $\left.\times g, 5 \mathrm{~min}, 20^{\circ} \mathrm{C}\right), 2 \times 1.5 \mathrm{~mL}$ of the supernatant were transferred into sterilized centrifuge tubes and centrifuged again for $30 \mathrm{~min}$ at $10,000 \times g$ and $20^{\circ} \mathrm{C}$. The supernatant was passed through a disposable $0.22-\mu \mathrm{m}$ sterile, pyrogen-free filter (Millex, Millipore Corporation, Bedford, MA). Afterward, samples were heated at $100^{\circ} \mathrm{C}$ for $30 \mathrm{~min}$ and then stored at $-20^{\circ} \mathrm{C}$ until analysis (Gozho et al., 2005).

Liver samples of approximately $30 \mathrm{mg}$ of tissue each were biopsied from half of each group ( $\mathrm{LC} \mathrm{n}=7, \mathrm{HC}$ $\mathrm{n}=7, \mathrm{HC} / \mathrm{MO} \mathrm{n}=8, \mathrm{HC} / \mathrm{EO} \mathrm{n}=8)$ after blood sampling on $\mathrm{d}-42(-40 \pm 7$; range $\mathrm{d}-56$ to -25$)$, $-14(-14 \pm 3$; range $\mathrm{d}-23$ to -10$),+7,+21$, and +56 relative to calving using an automated spring-loaded biopsy device (Bard Magnum, Bard, UK) with a 16-gauge needle under local anesthesia (procaine hydrochloride; Isocaine $2 \%$, Selectavet, Weyarn-Holzolling, Germany). In total, approximately $100 \mathrm{mg}$ of tissue were stored at $-80^{\circ} \mathrm{C}$.

\section{Analyses}

Serum samples were analyzed for haptoglobin concentration by an ELISA method as described previously (Hiss et al., 2004). Tryptophan and kynurenine

Table 1. Chemical composition of the experimental diets

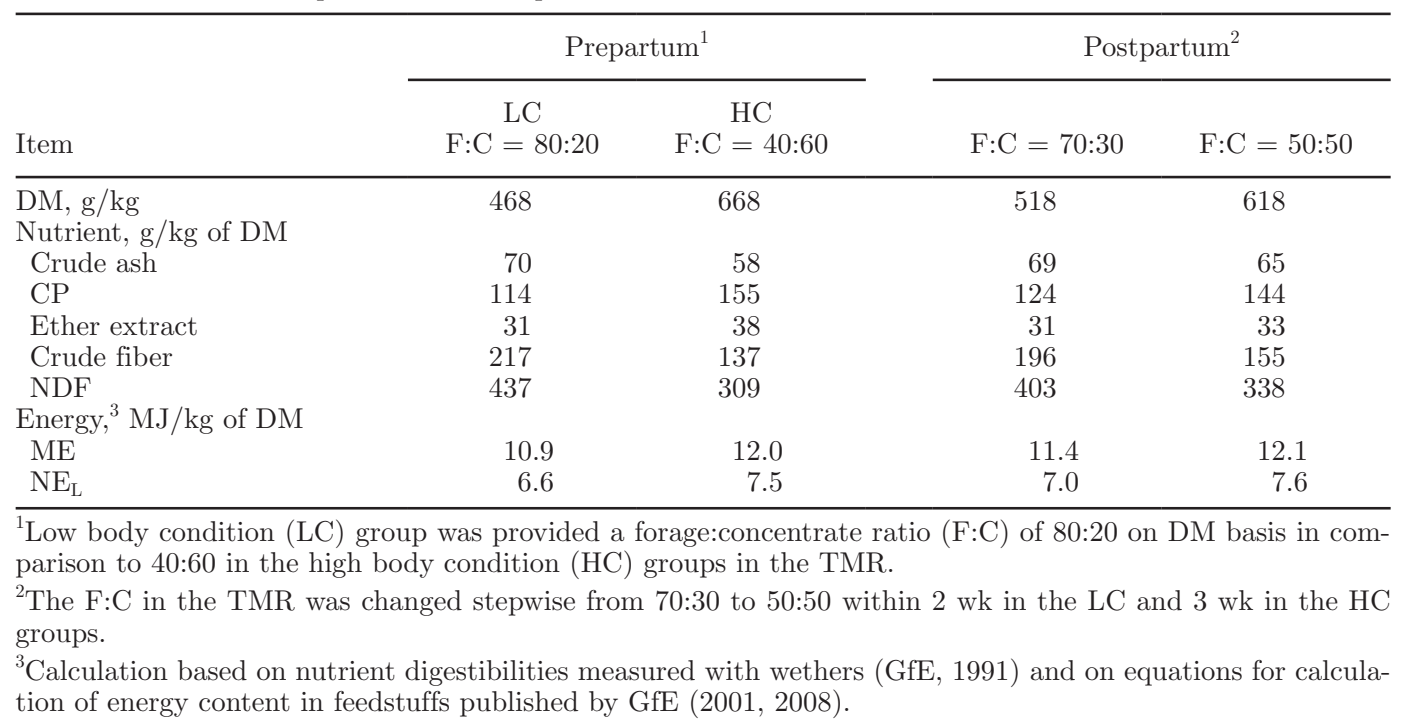


concentrations were determined in serum via HPLC after fat extraction with n-hexane and protein precipitation using cold ethanol. After centrifugation at $20,800 \times g$ for $10 \mathrm{~min}$ at $4^{\circ} \mathrm{C}$, the supernatant was quantitatively transferred into a flask and evaporated in a nitrogen stream at $40^{\circ} \mathrm{C}$. The residue was dissolved in aqueous mobile phase A. After filtration (syringe filter, polyvinylidene fluoride, $0.45 \mu \mathrm{m}$, Kinesis Ltd., St. Neots, UK), $20 \mu \mathrm{L}$ of the filtrate were injected into a Shimadzu HPLC system (Shimadzu, Kyoto, Japan). Samples were run through a C18 column (Inertsil ODS2, $150 \times 3 \mathrm{~mm}$ i.d., $5 \mu \mathrm{m}$, Agilent, Böblingen, Germany) at a flow rate of $0.5 \mathrm{~mL} / \mathrm{min}$ and were eluted using a binary gradient system. The mobile phase A consisted of sodium 1-hexanesulfonate monohydrate (IPCC6; 10 $\mathrm{m} M$ ) and $0.5 \%$ (vol/vol) acetonitrile in ultrapure water, adjusted to $\mathrm{pH} 2.3$ with $2 \mathrm{M}$ phosphoric acid. The mobile phase B was $100 \%$ acetonitrile. The detection wavelengths were $278 \mathrm{~nm}$ for tryptophan and $360 \mathrm{~nm}$ for kynurenine.

For assessing the ruminal LPS concentration, rumen fluid was thawed and centrifuged $(5 \mathrm{~min}, 1,500 \times g$, $20^{\circ} \mathrm{C}$ ). The Limulus amebocyte lysate assay (KineticQCLTM, Lonza, Walkersville, MD) was performed based on dilution and spectrophotometrical measurement of the samples following the manufacturer's instructions using a microplate reader (Infinite M200, Tecan Group Ltd., Männedorf, Switzerland), and finally evaluated using the MagellanTM Data Analysis Software (Tecan Group Ltd.) as described in full detail by Gozho et al. (2005).

\section{RNA Isolation}

Total RNA of liver tissue was isolated using an isolation procedure with a chaotropic ions buffer system and a silica membrane (NucleoSpin RNA II, Macherey Nagel, Düren, Germany) according to the manufacturer's protocol. Briefly, $30 \mathrm{mg}$ of frozen liver biopsy material added to $1.4 \mathrm{~mL}$ of lysis buffer RA1 with $\beta$-mercaptoethanol were immediately subjected to homogenization with an Ultra Turrax T25 (IKA, Staufen, Germany). After a 5-min centrifugation at 18,600 $\times g$ and $20^{\circ} \mathrm{C}, 350 \mu \mathrm{L}$ of the homogenate were used in the further isolation routine. Contaminating DNA was digested on-column and the RNA was eluted with $50 \mu \mathrm{L}$ of $\mathrm{H}_{2} \mathrm{O}$. Concentration and quality of the purified RNA were assessed spectrophotometrically with a NanoDrop ND-1000 (NanoDrop, Wilmington, DE). The RNA integrity was verified using $1.1 \%$ agarose gel electrophoresis. All samples exhibited intact bands corresponding to the $18 \mathrm{~S}$ and $28 \mathrm{~S}$ ribosomal RNA subunits; RNA was stored at $-80^{\circ} \mathrm{C}$ until further processing.

\section{cDNA Synthesis and Quantitative Real-Time PCR}

The cDNA was synthesized using $1 \mu \mathrm{g}$ of total RNA, 100 pmol of oligo(dT)18 primer (Eurofins MWG Operon, Ebersberg, Germany), $1.25 \mu \mathrm{L}$ of dNTP mix (10 $\mathrm{m} M$, GeneCraft, Lüdinghausen, Germany), $5 \mu \mathrm{L}$ of $5 \times$ RT reaction buffer (Thermo Fisher Scientific, St. Leon-Rot, Deutschland), and $60 \mathrm{U}$ of M-MuLV Reverse Transcriptase (Thermo Fisher Scientific) at $42^{\circ} \mathrm{C}$ for 60 min and a final inactivating step at $70^{\circ} \mathrm{C}$ for $10 \mathrm{~min}$ in a thermocycler (Biometra, Göttingen, Germany). The quantitative PCR runs were performed with a Rotorgene 2000 system (Corbett Research, Mortlake, Australia) using KAPA SYBR Fast qPCR Universal Mastermix (Peqlab, Erlangen, Germany) and gene-specific primer pairs from Eurofins MWG Operon (Ebersberg, Germany). Cycle threshold values of target and reference genes were obtained using the Rotorgene Software 5.0 (Corbett Research, Mortlake, Australia). Determination of relative expression levels was calculated using GeNorm normalization factor including the 3 most stable out of 6 reference genes (Vandesompele et al., 2012). Gene-specific primer pairs were designed using Primer3 and BLAST (https://www.ncbi.nlm.nih.gov/ tools/primer-blast/). Amplified products were checked by $2.5 \%$ agarose gel electrophoresis. Characteristics of primers used for quantitative PCR analysis are shown in Table 2.

\section{Statistical Analyses}

All statistical analyses were performed using the MIXED procedure for repeated measures (Littell et al., 1998) in SAS Software (ver. 9.2, SAS Institute Inc., Cary, NC). After testing various covariance structures, compound symmetry covariance structure was used showing the lowest Akaike information criterion. A repeated statement was considered in the model to account for the individual variation of the cows. The model contained treatment (LC, HC, HC/MO, and $\mathrm{HC} / \mathrm{EO}$ ) and time (sampling days) as fixed effects as well as the interaction between these factors. All data were log-transformed before analyses because of inhomogeneity of variances and then back transformed for presentation. The Tukey-Kramer test was applied for a multiple comparison of means. Orthogonal contrasts were used to test the main differences between LC and $\mathrm{HC}$ cows (LC vs. HC) and the supplementation of monensin (HC vs. $\mathrm{HC} / \mathrm{MO}$ ) and essential oils in high condition cows ( $\mathrm{HC}$ vs. HC/EO). Effects were declared significant when $\mathrm{p}$-values were $<0.05$. All parameters are presented as least squares means and standard error of the mean. Spearman correlation coefficients were 
calculated by using the Statistica Software (ver. 12, StatSoft Inc., Tulsa, OK).

\section{RESULTS}

\section{Animals}

Out of 60 cows, 55 animals completed the entire trial and 1 cow was removed at d 28 (HC/EO group) from the experiment because of an abomasal displacement. Additionally, 4 cows were excluded from the whole study because of illnesses that were not associated with the experimental treatments ( 1 cow of $\mathrm{LC}$ and $\mathrm{HC} /$ MO group, 2 cows of $\mathrm{HC}$ group); causes were abomasal displacement (1 cow of LC group) and multisystemic health problems around calving ( 1 cow of $\mathrm{HC} / \mathrm{MO}$ group, 2 cows of HC group).

\section{Effect on Serum Haptoglobin and the Kynurenine- to-Tryptophan Ratio}

Serum haptoglobin concentration was not different between groups $(P=0.489)$ but was dependent on time $(P<0.001)$, as it increased from $\mathrm{d}-3$ on with a peak at $\mathrm{d} 7$ in all groups and thereafter declined to starting values from d 21 on (Figure 1). The kynurenine-totryptophan ratio is presented in Figure 2. It changed in course of time $(P<0.001)$, whereby it first increased until a peak was reached at $\mathrm{d} 1$ and then decreased to a nadir on $\mathrm{d}$ 7. The ratio was generally higher in LC than

Table 2. Characteristics of gene specific primers used for quantitative PCR

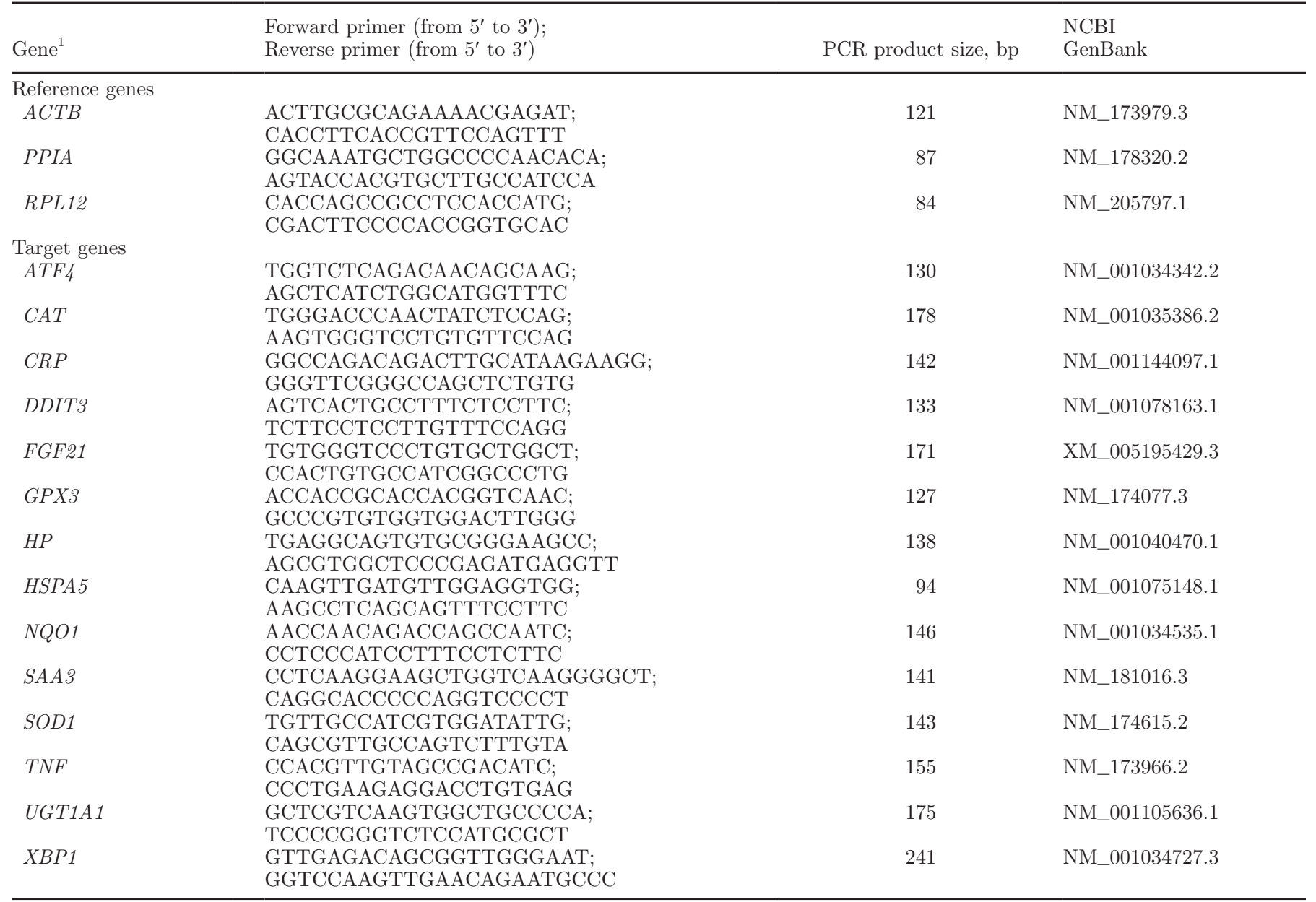

$\overline{{ }^{1} A C T B}=$ actin $\beta ; A T F 4=$ activating transcription factor $4 ; C A T=$ catalase; $C R P=$ C-reactive protein; DDIT3 $=$ DNA-damage-inducible transcript 3; FGF21 = fibroblast growth factor 21; GPX3 = glutathione peroxidase 3; HP= haptoglobin; HSPA5 = heat shock 70-kDa protein $5 ; N Q O 1=\mathrm{NAD}(\mathrm{P}) \mathrm{H}$ quinone dehydrogenase $1 ; P P I A=$ peptidylprolyl isomerase A; RPL12= ribosomal protein L12; SAA3= serum amyloid A $3 ; S O D 1=$ superoxide dismutase 1 , soluble; $T N F=$ tumor necrosis factor; $U G T 1 A 1=$ UDP glucuronosyltransferase family 1 member A1; $X B P 1=\mathrm{X}$-box binding protein 1. 
in $\mathrm{HC} / \mathrm{MO}$ treatment $(P=0.022)$ and at $\mathrm{d} 7$, resulting in a treatment $\times$ time interaction $(P=0.040)$.

\section{Effect on Ruminal LPS Concentration}

The ruminal LPS concentration was different between groups $(P=0.040)$, whereby greater values were observed in $\mathrm{HC} / \mathrm{MO}$ than in $\mathrm{HC}$ cows $(P=0.035$, Table 3).

\section{Effect on NF-KB Target Genes}

The mRNA abundance of nuclear factor kappa B $(\mathbf{N F}-\boldsymbol{\kappa B})$ target genes $\mathrm{C}$-reactive protein $(C R P)$, haptoglobin $(H P)$, serum amyloid A 3 (SAA3), and tumor necrosis factor $(T N F)$ in the liver are presented in Table 4. The expression of $T N F$ was not different between the groups and over time, whereas the mRNA abundance of the acute phase proteins $C R P, S A A 3$, and $H P$ was dependent on time (all $P<0.001$ ). The $C R P$ mRNA generally increased from $\mathrm{d}-42$ to -14 and $+7(P=$ 0.002 and 0.014 , respectively) and decreased thereafter; it was higher in $\mathrm{HC} / \mathrm{EO}$ cows at $\mathrm{d}-14$ than at $\mathrm{d}$ $-42(P=0.038)$. The mRNA abundance of $S A A 3$ and $H P$ developed similarly over the course of trial: both increased from antepartum until a peak on $\mathrm{d} 7(P<$

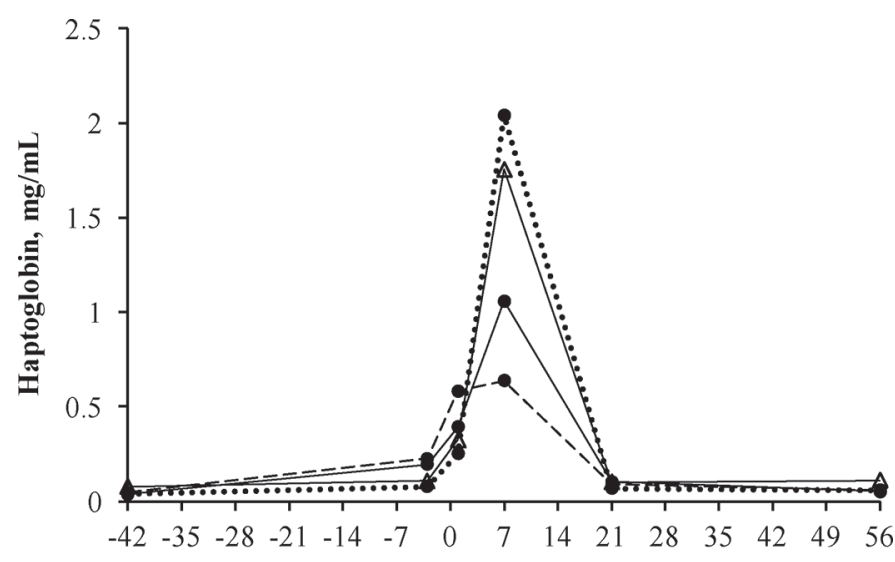

Experimental day relative to calving

Figure 1. Serum haptoglobin concentrations during the trial. Cows received a low-concentrate $(\Delta)$ diet with a forage-to-concentrate ratio of 80:20 $(\mathrm{n}=14)$ or a high-concentrate $(\bullet)$ diet with a forage-to-concentrate ratio of 40:60 antepartum. Postpartal forage-to-concentrate ratio was changed stepwise from 70:30 to 50:50 within $2 \mathrm{wk}$ in the lowconcentrate group $(\Delta ; \mathrm{LC})$ and $3 \mathrm{wk}$ in the high-concentrate groups $(\bullet$ HC). Treatment included no supplementation (solid line; $\mathrm{n}=13$ ), the administration of a monensin controlled-release capsule (MO; dotted line; $\mathrm{n}=14$ ) at $\mathrm{d}-21$, and the addition of $1 \mathrm{~g} / \mathrm{d}$ per cow of a blend of essential oils (EO; dashed line; $\mathrm{n}=15$ ) from $\mathrm{d}-21$ until +56 relative to calving. ANOVA: $P_{\text {treatment }}=0.489, P_{\text {time }}<0.001, P_{\text {treatment } \times \text { time }}$ $=0.182, \mathrm{SEM}=0.385$. Contrast: $P_{\mathrm{LC} \text { vs. } \mathrm{HC}}=0.848, P_{\mathrm{HC} \text { vs. } \mathrm{HC} / \mathrm{MO}}=$ $0.892, P_{\mathrm{HC} \text { vs } \mathrm{HC} / \mathrm{EO}}=0.999$.
0.001) and then declined subsequently. This increase was not significant in $\mathrm{HC}$ group. Expression of $H P$ was dependent on treatment $(P=0.047)$, driven primarily by a trend for a higher mRNA abundance in LC than in $\mathrm{HC} / \mathrm{EO}$ group $(P=0.081)$.

\section{Effect on Nrf2 Target Genes}

The mRNA abundance of Nrf2 target genes catalase $(C A T)$, glutathione peroxidase 3 (GPX3), $\mathrm{NAD}(\mathrm{P})$ $\mathrm{H}$ quinone dehydrogenase 1 (NQO1), superoxide dismutase 1 (SOD1), and UDP glucuronosyltransferase family 1 member A1 (UGT1A1) in the liver are presented in Table 5. Expression of Nrf2 target genes with detoxifying functions was not different between groups and over time, as shown for NQO1 and UGT1A. In contrast, the abundance of GPX3 and CAT as target genes with antioxidative properties was highly dependent on time (both $P<0.001$ ). Expression of GPX3 increased in $\mathrm{LC}, \mathrm{HC}$, and $\mathrm{HC} / \mathrm{MO}$ group from $\mathrm{d}-42$ to a peak on $\mathrm{d}+7$ (all $P<0.005$, Figure 3 ). Meanwhile, it was higher in LC than in $\mathrm{HC} / \mathrm{EO}$ group over the whole experiment $(P=0.015)$, resulting in a treatment effect $(P=0.025)$. Abundance of $C A T$ was not different between groups but dependent on time $(P<0.001)$, as it generally dropped from $\mathrm{d}-14$ to +7 and $+21(P=$

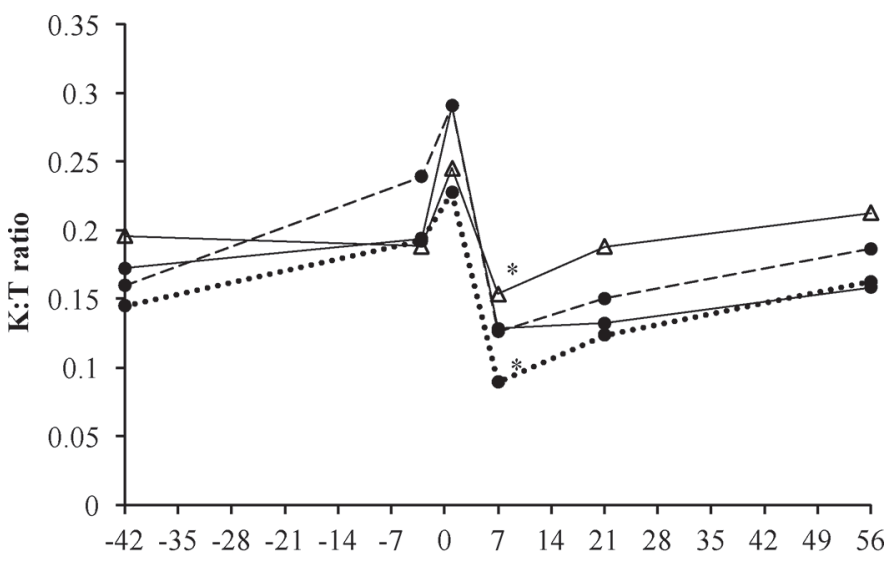

Experimental day relative to calving

Figure 2. The serum kynurenine-to-tryptophan (K:T) ratio during the trial. Cows received a low-concentrate $(\Delta)$ diet with a forage-toconcentrate ratio of 80:20 $(\mathrm{n}=14)$ or a high-concentrate $(\bullet)$ diet with a forage-to-concentrate ratio of 40:60 antepartum. Postpartal forageto-concentrate ratio was changed stepwise from 70:30 to 50:50 within 2 wk in the low-concentrate group $(\Delta ; \mathrm{LC})$ and 3 wk in the high-concentrate groups $(\mathbf{\bullet}$ HC). Treatment included no supplementation (solid line; $\mathrm{n}=13$ ), the administration of a monensin controlled-release capsule $(\mathrm{MO}$; dotted line; $\mathrm{n}=14$ ) at $\mathrm{d}-21$, and the addition of $1 \mathrm{~g} / \mathrm{d}$ per cow of a blend of essential oils (EO; dashed line; $\mathrm{n}=15$ ) from $\mathrm{d}$ -21 until +56 relative to calving. ANOVA: $P_{\text {treatment }}=0.022, P_{\text {time }}<$ $0.001, P_{\text {treatment } x \text { time }}=0.040, \mathrm{SEM}=0.01$. Contrast: $P_{\mathrm{LC} \mathrm{vs.} \mathrm{HC}}=0.487$, $P_{\mathrm{HC} \text { vs. } \mathrm{HC} / \mathrm{MO}}=0.402, P_{\mathrm{HC} \text { vs. } \mathrm{HC} / \mathrm{EO}}=0.861 .{ }^{*} P<0.05, \mathrm{LC}$ vs. $\mathrm{HC} / \mathrm{MO}$. 
Table 3. Ruminal free LPS concentration (endotoxin units/mL) of cows during the postpartal phase of the trial from d 7 until 56 after calving

\begin{tabular}{|c|c|c|c|c|c|c|c|c|c|c|c|}
\hline Day & \multicolumn{4}{|c|}{ Treatment $^{1}$} & SEM & Treatment & Time & \multicolumn{3}{|c|}{$P$-value } & \\
\hline 7 & 6,303 & 844 & 6,352 & 2,829 & 2,268 & 0.040 & 0.482 & 0.678 & 0.126 & 0.035 & 0.503 \\
\hline 14 & 4,840 & 527 & 4,837 & 1,792 & 1,683 & & & & & & \\
\hline 21 & 5,807 & 421 & 6,344 & 2,241 & 1,808 & & & & & & \\
\hline
\end{tabular}

${ }^{1}$ Treatment $=$ high BCS groups $(\mathrm{HC} / \mathrm{Control}, \mathrm{n}=4 ; \mathrm{HC} / \mathrm{MO}, \mathrm{n}=4 ; \mathrm{HC} / \mathrm{EO}, \mathrm{n}=4$ ) received a concentrate proportion of $60 \%$ (HC); low BCS cows $(n=4)$ were fed a concentrate proportion of $20 \%(\mathrm{LC})$ in the prepartal diet. Postcalving, the concentrate proportion in the diet was increased from 30 to $50 \%$ within 2 wk in LC group and 3 wk in HC groups. HC/MO were administered a monensin (MO) controlled-release capsule (Kexxtone, Elanco, Bad Homburg, Germany) at d -21, HC/EO received $1 \mathrm{~g} / \mathrm{d}$ of a blend of essential oils (EO; Crina Ruminants, DSM, Basel, Switzerland) from d -21 until d +56 relative to calving.

0.002 and $P=0.013$, respectively) and increased again until d $+56(P<0.05)$. Meanwhile, it decreased in $\mathrm{HC} /$ MO group from $\mathrm{d}-14$ to $+7(P=0.002)$ and then increased until d $+56(P=0.035)$. Gene expression of $S O D 1$ was independent of time and treatment.

\section{Effect on UPR Target Genes}

The mRNA abundance of UPR target genes activating transcription factor 4 (ATF4), DNA-damage-inducible transcript 3 (DDIT3), fibroblast growth factor 21

Table 4. Relative mRNA abundance of nuclear factor- $\kappa \mathrm{B}$ target genes in the liver of cows during the trial from $\mathrm{d}-42$ until +56 relative to calving $^{1}$

\begin{tabular}{|c|c|c|c|c|c|c|c|c|c|c|c|}
\hline Item $^{2}$ & \multicolumn{4}{|c|}{ Treatment $^{3}$} & SEM & Treatment & Time & \multicolumn{3}{|c|}{$P$-value } & \\
\hline$C R P$ & & & & & & 0.691 & $<0.001$ & 0.085 & 0.859 & 0.987 & 0.859 \\
\hline $\mathrm{d}-42$ & 1.00 & 0.65 & 0.62 & $0.47^{\mathrm{B}}$ & 0.13 & & & & & & \\
\hline $\mathrm{d}-14$ & 0.84 & 1.07 & 1.11 & $1.00^{\mathrm{A}}$ & 0.35 & & & & & & \\
\hline $\mathrm{d}+56$ & 0.81 & 0.80 & 0.59 & $0.55^{\mathrm{AB}}$ & 0.22 & & & & & & \\
\hline$H P$ & & & & & & 0.047 & $<0.001$ & 0.394 & 0.993 & 0.383 & 0.139 \\
\hline $\mathrm{d}-42$ & 1.00 & $0.22^{\mathrm{B}}$ & $0.05^{\mathrm{B}}$ & $0.09^{\mathrm{B}}$ & 0.02 & & & & & & \\
\hline $\mathrm{d}-14$ & 1.39 & $1.65^{\mathrm{AB}}$ & $0.55^{\mathrm{B}}$ & $0.27^{\mathrm{AB}}$ & 0.14 & & & & & & \\
\hline $\mathrm{d}+7$ & 8.08 & $7.43^{\mathrm{A}}$ & $14.59^{\mathrm{A}}$ & $3.36^{\mathrm{A}}$ & 0.17 & & & & & & \\
\hline $\mathrm{d}+21$ & 2.39 & $0.99^{\mathrm{AB}}$ & $0.88^{\mathrm{B}}$ & $0.95^{\mathrm{AB}}$ & 0.06 & & & & & & \\
\hline $\mathrm{d}+56$ & 0.29 & $1.46^{\mathrm{AB}}$ & $0.17^{\mathrm{B}}$ & $0.16^{\mathrm{AB}}$ & 0.05 & & & & & & \\
\hline $\mathrm{d}+56$ & $0.97^{\mathrm{B}}$ & $2.32^{\mathrm{AB}}$ & $1.83^{\mathrm{AB}}$ & $2.02^{\mathrm{AB}}$ & 0.08 & & & & & & \\
\hline$T N F$ & & & & & & 0.933 & 0.178 & 0.634 & 0.992 & 0.949 & 0.992 \\
\hline $\mathrm{d}-42$ & 1.00 & 0.83 & 0.92 & 0.80 & 0.02 & & & & & & \\
\hline $\mathrm{d}-14$ & 1.04 & 1.19 & 1.00 & 1.11 & 0.02 & & & & & & \\
\hline $\mathrm{d}+7$ & 1.02 & 1.25 & 0.98 & 0.66 & 0.01 & & & & & & \\
\hline $\mathrm{d}+21$ & 0.90 & 1.00 & 0.92 & 1.15 & 0.02 & & & & & & \\
\hline $\mathrm{d}+56$ & 1.16 & 1.24 & 1.02 & 1.20 & 0.02 & & & & & & \\
\hline
\end{tabular}

\footnotetext{
${ }_{\mathrm{A}, \mathrm{B}}$ Least squares means within column with different superscripts differ $(P<0.05)$.

${ }^{1}$ Presented mRNA abundance is expressed relative to mRNA abundances of low condition group at $\mathrm{d}-42$.

${ }^{2} C R P=$ C-reactive protein; $H P=$ haptoglobin; $S A A 3=$ serum amyloid A $3 ; T N F=$ tumor necrosis factor.

${ }^{3}$ Treatment: high BCS groups (HC/Control, $\mathrm{n}=7 ; \mathrm{HC} / \mathrm{MO}, \mathrm{n}=8 ; \mathrm{HC} / \mathrm{EO}, \mathrm{n}=8$ ) received a concentrate proportion of $60 \%$ (HC); low BCS cows $(\mathrm{n}=7)$ were fed a concentrate proportion of $20 \%(\mathrm{LC})$ in the prepartal diet. Postcalving, the concentrate proportion in the diet was increased from 30 to $50 \%$ within $2 \mathrm{wk}$ in LC group and 3 wk in HC groups. HC/MO was administered a monensin (MO) controlled-release capsule (Kexxtone, Elanco, Bad Homburg, Germany) at d -21, HC/EO received $1 \mathrm{~g} / \mathrm{d}$ of a blend of essential oils (EO; Crina Ruminants, DSM, Basel, Switzerland) from $\mathrm{d}-21$ until $\mathrm{d}+56$ relative to calving.
} 
(FGF21), heat shock $70-\mathrm{kDa}$ protein 5 (HSPA5), and $\mathrm{X}$-box binding protein 1 (XBP1) in the liver are presented in Table 6 . The expression of most genes was not different between groups but was dependent on time (all $P<0.05$ ), except for DDIT3. The abundance of HSPA 5 was generally higher on $\mathrm{d}+7$ than on -42 and $-14(P=0.025$ and 0.017 , respectively $)$, whereas it peaked on $\mathrm{d}+7$ in the $\mathrm{LC}, \mathrm{HC}$, and $\mathrm{HC} / \mathrm{MO}$ groups but peaked on $\mathrm{d}-14$ in $\mathrm{HC} / \mathrm{EO}$ cows. The abundance of ATF 4 was higher on $\mathrm{d}+7$ than on $\mathrm{d}-14(P=$ $0.022)$.

The expression of XBP1 generally increased from $\mathrm{d}-42$ to $+7(P<0.001)$ and decreased until $\mathrm{d}+56$ $(P=0.011)$. The increase was only significant in $\mathrm{HC} /$ MO group $(P=0.014)$. The mRNA expression was lower in $\mathrm{HC} / \mathrm{EO}$ cows on $\mathrm{d} 7$ than in $\mathrm{HC} / \mathrm{MO}$ group $(P$ $=0.015)$, resulting in a trend for a treatment $\times$ time interaction $(P=0.061$, Figure 3$)$. The abundance of FGF21 generally first declined from d -42 to $-14(P=$ 0.010 ) and then increased until the postpartal period. The expression was higher on all postpartal sampling days than on $\mathrm{d}-14$ in $\mathrm{HC}$ cows (all $P<0.05$ ) and on $\mathrm{d}$ +21 than on $\mathrm{d}-14$ in the $\mathrm{HC} / \mathrm{MO}$ group $(P=0.019)$.

\section{DISCUSSION}

\section{Effect of Body Condition, Concentrate Feeding, and Time}

One objective of our study was to assess the occurrence of inflammatory-like phenomena in transition

Table 5. Relative mRNA abundance of nuclear factor E2-related factor 2 target genes in the liver of cows during the trial from $d-42$ until +56 relative to calving ${ }^{1}$

\begin{tabular}{|c|c|c|c|c|c|c|c|c|c|c|c|}
\hline \multirow[b]{3}{*}{ Item $^{2}$} & \multicolumn{4}{|c|}{ Treatment $^{3}$} & \multirow[b]{3}{*}{ SEM } & \multirow[b]{3}{*}{ Treatment } & \multirow[b]{3}{*}{ Time } & \multicolumn{3}{|c|}{$P$-value } & \\
\hline & & & $\mathrm{HC}$ & & & & & \multirow{2}{*}{$\begin{array}{l}\text { Treatment } \\
\times \text { time }\end{array}$} & \multicolumn{3}{|c|}{ Contrast } \\
\hline & $\mathrm{LC}$ & Control & MO & $\mathrm{EO}$ & & & & & LC vs. HC & $\mathrm{HC}$ vs. $\mathrm{HC} / \mathrm{MO}$ & $\mathrm{HC}$ vs. $\mathrm{HC} / \mathrm{EO}$ \\
\hline$C A T$ & & & & & & 0.635 & $<0.001$ & 0.121 & 0.712 & 0.989 & 0.732 \\
\hline $\mathrm{d}-42$ & 1.00 & 0.84 & $1.07^{\mathrm{AB}}$ & 0.98 & 0.02 & & & & & & \\
\hline $\mathrm{d}-14$ & 0.96 & 1.08 & $1.31^{\mathrm{A}}$ & 1.43 & 0.06 & & & & & & \\
\hline $\mathrm{d}+7$ & 1.01 & 0.89 & $0.60^{\mathrm{B}}$ & 0.87 & 0.26 & & & & & & \\
\hline $\mathrm{d}+21$ & 1.11 & 0.77 & $0.79^{\mathrm{AB}}$ & 0.86 & 0.13 & & & & & & \\
\hline$d+56$ & 1.14 & 1.04 & $1.16^{\mathrm{A}}$ & 1.13 & 0.05 & & & & & & \\
\hline$G P X 3$ & & & & & & 0.025 & $<0.001$ & 0.363 & 0.619 & 0.976 & 0.214 \\
\hline $\mathrm{d}-42$ & $1.00^{\mathrm{B}}$ & $0.32^{\mathrm{B}}$ & $0.20^{\mathrm{B}}$ & 1.07 & 0.29 & & & & & & \\
\hline $\mathrm{d}-14$ & $1.61^{\mathrm{AB}}$ & $0.79^{\mathrm{AB}}$ & $0.27^{\mathrm{B}}$ & 1.10 & 0.36 & & & & & & \\
\hline $\mathrm{d}+7$ & $18.35^{\mathrm{A}}$ & $7.43^{\mathrm{A}}$ & $19.05^{\mathrm{A}}$ & 0.91 & 0.35 & & & & & & \\
\hline $\mathrm{d}+21$ & $4.41^{\mathrm{AB}}$ & $1.57^{\mathrm{AB}}$ & $3.05^{\mathrm{AB}}$ & 0.87 & 0.25 & & & & & & \\
\hline $\mathrm{d}+56$ & $1.97^{\mathrm{AB}}$ & $3.84^{\mathrm{AB}}$ & $1.35^{\mathrm{AB}}$ & 1.02 & 0.27 & & & & & & \\
\hline$N Q O 1$ & & & & & & 0.895 & 0.239 & 0.321 & 0.979 & 0.916 & 0.999 \\
\hline $\mathrm{d}-42$ & 1.00 & 1.02 & 1.26 & 0.80 & 0.02 & & & & & & \\
\hline $\mathrm{d}-14$ & 1.20 & 1.18 & 1.22 & 1.11 & 0.02 & & & & & & \\
\hline $\mathrm{d}+7$ & 1.11 & 1.06 & 0.97 & 0.66 & 0.01 & & & & & & \\
\hline $\mathrm{d}+21$ & 1.06 & 1.03 & 0.89 & 1.15 & 0.02 & & & & & & \\
\hline $\mathrm{d}+56$ & 1.09 & 0.93 & 1.35 & 1.20 & 0.02 & & & & & & \\
\hline$S O D 1$ & & & & & & 0.658 & 0.531 & 0.430 & 0.962 & 0.899 & 0.995 \\
\hline $\mathrm{d}-42$ & 1.00 & 0.99 & 1.01 & 0.98 & 0.12 & & & & & & \\
\hline $\mathrm{d}-14$ & 1.12 & 1.09 & 0.98 & 1.43 & 0.17 & & & & & & \\
\hline $\mathrm{d}+7$ & 1.35 & 1.09 & 0.86 & 0.87 & 0.18 & & & & & & \\
\hline $\mathrm{d}+21$ & 1.19 & 0.90 & 0.84 & 0.86 & 0.15 & & & & & & \\
\hline $\mathrm{d}+56$ & 1.07 & 1.08 & 0.75 & 1.13 & 0.11 & & & & & & \\
\hline$U G T 1 A 1$ & & & & & & 0.803 & 0.102 & 0.286 & 0.776 & 0.883 & 0.992 \\
\hline $\mathrm{d}-42$ & 1.00 & 0.78 & 1.15 & 1.20 & 0.13 & & & & & & \\
\hline $\mathrm{d}-14$ & 1.19 & 0.84 & 1.15 & 1.12 & 0.12 & & & & & & \\
\hline $\mathrm{d}+7$ & 1.11 & 0.89 & 0.73 & 1.13 & 0.16 & & & & & & \\
\hline $\mathrm{d}+21$ & 1.15 & 0.70 & 0.95 & 0.95 & 0.15 & & & & & & \\
\hline $\mathrm{d}+56$ & 1.08 & 0.91 & 1.20 & 0.86 & 0.12 & & & & & & \\
\hline
\end{tabular}

$\overline{\mathrm{A}, \mathrm{B}}$ Least squares means within column with different superscripts differ $(P<0.05)$.

${ }^{1}$ Presented mRNA abundance is expressed relative to mRNA abundances of low condition group at d -42 .

${ }^{2} C A T=$ catalase; $G P X 3=$ glutathione peroxidase $3 ; N Q O 1=\mathrm{NAD}(\mathrm{P}) \mathrm{H}$ quinone dehydrogenase $1 ; S O D 1=$ superoxide dismutase 1 , soluble; UGT1A1 = UDP glucuronosyltransferase family 1 member A1.

${ }^{3}$ Treatment: high BCS groups ( $\mathrm{HC} /$ Control, $\mathrm{n}=7 ; \mathrm{HC} / \mathrm{MO}, \mathrm{n}=8 ; \mathrm{HC} / \mathrm{EO}, \mathrm{n}=8$ ) received a concentrate proportion of $60 \%$ (HC); low BCS cows $(\mathrm{n}=7)$ were fed a concentrate proportion of $20 \%(\mathrm{LC})$ in the prepartal diet. Postcalving, the concentrate proportion in the diet was increased from 30 to $50 \%$ within $2 \mathrm{wk}$ in LC group and $3 \mathrm{wk}$ in $\mathrm{HC}$ groups. HC/MO was administered a monensin (MO) controlled-release capsule (Kexxtone, Elanco, Bad Homburg, Germany) at d -21, HC/EO received $1 \mathrm{~g} / \mathrm{d}$ of a blend of essential oils (EO; Crina Ruminants, DSM, Basel, Switzerland) from $\mathrm{d}-21$ until $\mathrm{d}+56$ relative to calving. 

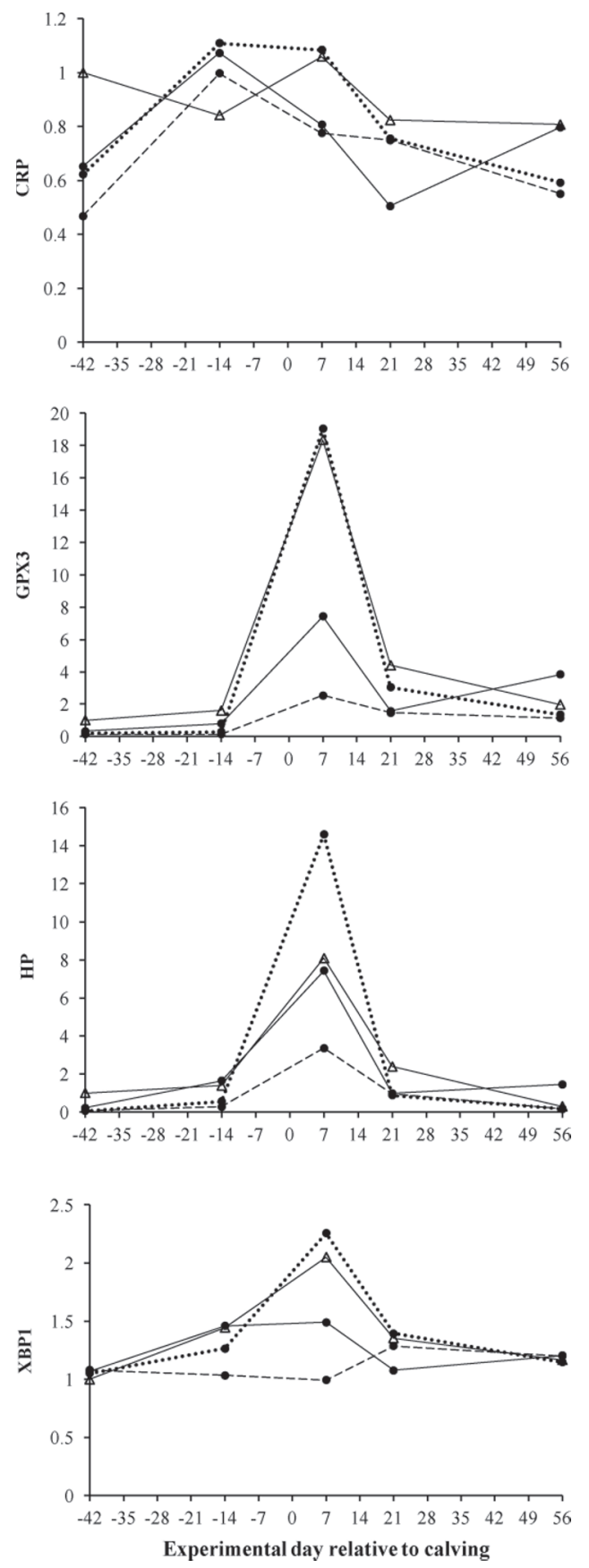

Figure 3. Relative mRNA abundance of C-reactive protein $(C R P)$, haptoglobin $(H P)$, glutathione peroxidase $3(G P X 3)$, and X-box binding protein $1(X B P 1)$ in liver biopsies during the trial. Cows received a low-concentrate $(\Delta)$ diet with a forage-to-concentrate ratio of 80:20 $(\mathrm{n}=7)$ or a high-concentrate $(\bullet)$ diet with a forage-to-concentrate ratio of 40:60 antepartum. Postpartal forage-to-concentrate ratio was changed stepwise from 70:30 to 50:50 within 2 wk in the low-concentrate group $(\Delta ; \mathrm{LC})$ and $3 \mathrm{wk}$ in the high-concentrate groups ( $\mathrm{HC}$ ). Treatment included no supplementation (solid line; $\mathrm{n}=7$ ), the administration of a monensin controlled-release capsule (MO; dotted line; $\mathrm{n}=8$ ) at $\mathrm{d}-21$, and the addition of $1 \mathrm{~g} / \mathrm{d}$ per cow of a blend of essential oils (EO; dashed line; $\mathrm{n}=8$ ) from $\mathrm{d}-21$ until +56 relative to calving. Presented mRNA abundance is expressed relative to mRNA abundance of low concentrate group $(\Delta)$ at d -42 . CRP: $\mathrm{SEM}=0.22$; $H P: \mathrm{SEM}=0.09 ; G P X 3: \mathrm{SEM}=0.30 ; X B P 1: \mathrm{SEM}=0.08$. cows around calving taking account of prepartal body condition and concentrate feeding. Therefore, we evaluated inflammatory markers in blood and the expression of several genes in liver biopsy samples around calving. An animal model was applied that makes use of a combination of the factors high BCS antepartum, overfeeding in dry period, and a decelerated energy supply postpartum to create animal groups being subjected to a ketogenic metabolic status (Schulz et al., 2014). In fact, fatty acid concentration was more than twice as high and prevalence of either subclinical or clinical ketosis (BHB concentration $>1.2 \mathrm{mmol} / \mathrm{L}$ ) was $36 \%$ higher in the HC than the LC group. Supplementation of monensin decreased ketogenesis in high-conditioned cows, although fatty acid mobilization stayed unaltered whereas supplementation of essential oils failed to elicit any effect (Drong et al., 2016a). The DMI was $3.3 \mathrm{~kg} / \mathrm{d}$ higher in $\mathrm{HC} / \mathrm{MO}$ than in LC cows in dry period and was not different between the groups after calving, as was milk yield (Drong et al., 2016a).

The mRNA abundances of acute phase proteins in liver biopsies, as well as the evaluated parameters in blood, gave evidence of the occurrence of inflammatorylike processes in dairy cows directly after calving. The kynurenine-to-tryptophan ratio provides indirect information about the activity of the enzyme indoleamine 2,3-dioxygenase (Hayaishi, 1976). Its activity is high during immune system activation after stimulation by cytokines in times of inflammation or infectious diseases (de Jong et al., 2009). Therefore, the ratio is regarded as an indicator for an activated immune system (Werner et al., 1987; Schröcksnadel et al., 2003). The ratio was shown to be increased in cattle in the period of peri-implantation, whereby the higher indoleamine 2,3-dioxygenase activity was suggested to establish the embryo tolerance in the bovine (Groebner et al., 2011) and also at birth in women (Schröcksnadel et al., 1996); similarly, the ratio peaked on d 1 in the present study. Together with the prominent peak of serum haptoglobin concentration on $\mathrm{d} 7$, it emphasizes the great effect of the event of calving on the immune response, as we have already described for several further immune function parameters and immune populations (Drong et al., 2016b). Meanwhile, the peak was about 3-fold higher in $\mathrm{HC}$ than in $\mathrm{LC}$ cows compared with that at $\mathrm{d}-42$ (Figure 1).

Whereas the mRNA abundance of TNF did not seem to play a role as an inflammatory marker in the present study, the mRNA of $S A A 3$ and $H P$, in particular, showed a distinct peak also on $\mathrm{d} 7$ in all groups. The serum haptoglobin concentration was positively correlated with the mRNA abundance of $C R P(\mathrm{r}=0.28, P$ $=0.002), S A A 3(\mathrm{r}=0.48, P<0.001)$, and $H P(\mathrm{r}=$ $0.74, P<0.001)$. 
The different antepartal concentrate proportions in LC $(20 \%)$ and HC cows (60\%) did not influence postpartal ruminal LPS concentration. One reason might be the similar concentrate proportion postpartum when ruminal LPS was determined which might mask the antepartal concentrate effect. However, Penner et al. (2007) also reported that feeding additional concentrate antepartum did not influence postpartal ruminal acidosis. A low ruminal $\mathrm{pH}$ is accompanied by an increase in free ruminal LPS, as it leads to an increased bacterial cell death, lysis, and release of LPS that is part of the outer membrane of gram-negative bacteria (Nagaraja et al., 1978; Rietschel et al., 1994). In this context, high concentrate proportions can potentially cause an al- teration of the ruminal microbiota population (Mao et al., 2013) and an accumulation of organic acids, such as short-chain fatty acids and lactate, in the rumen, with possible consequences for rumen health such as SARA (Plaizier et al., 2008; Zebeli et al., 2015). The impairment of the gut mucosa and the potentially increased translocation of immunogenic compounds such as LPS into the systemic blood circulation were reported to be contributing factors to the presence of inflammatory phenomena in early-lactating dairy cows (Ringseis et al., 2015). In accordance, several studies reported increased free ruminal LPS concentrations and a subsequent induction of a systemic inflammatory response, as seen in increased concentrations of different acute

Table 6. Relative mRNA abundance of unfolded protein response target genes in the liver of cows during the trial from d $-42 \mathrm{until}+56$ relative to calving ${ }^{1,2}$

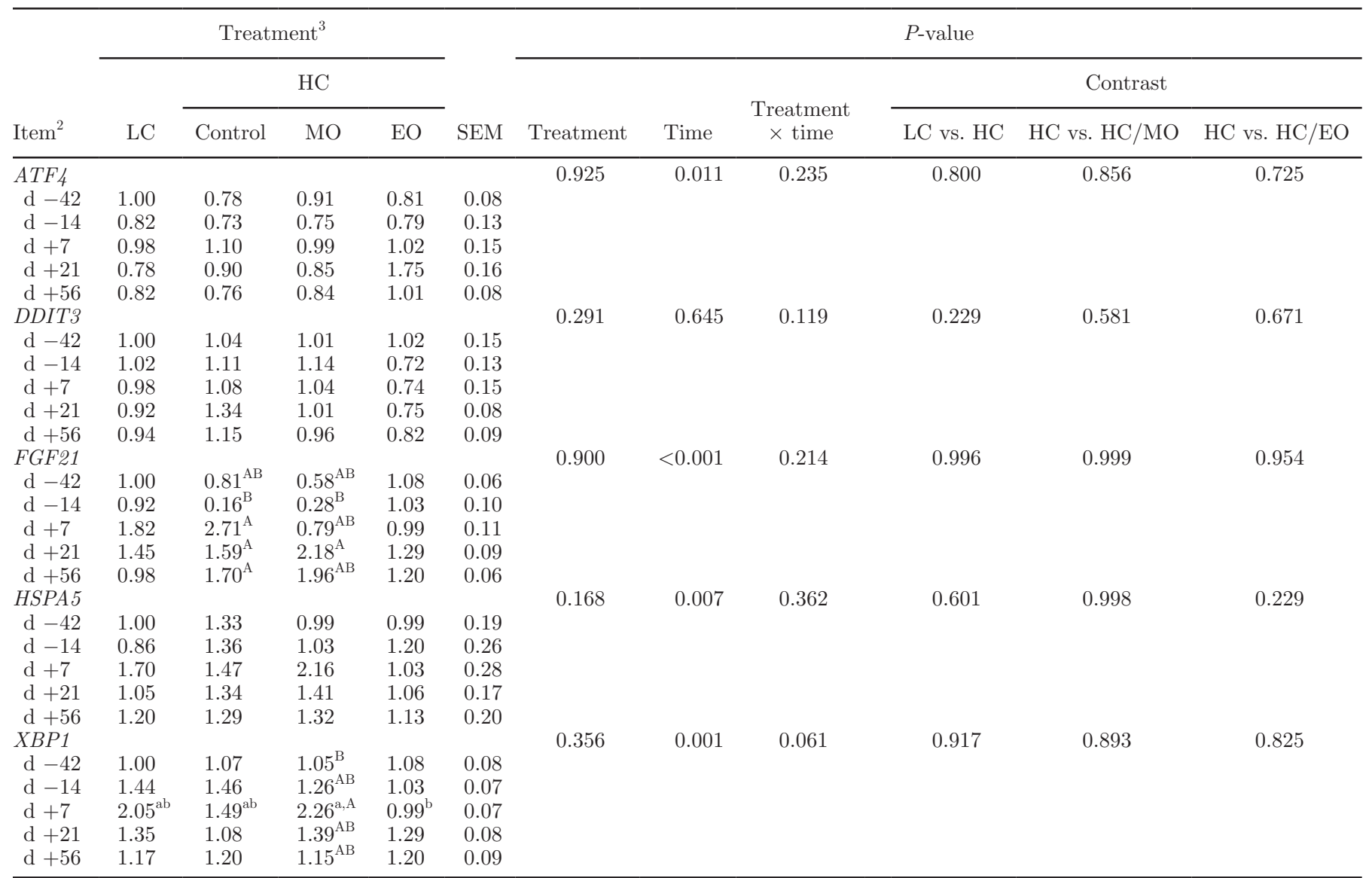

\footnotetext{
${ }^{\mathrm{a}, \mathrm{b}}$ Least squares means within row with different superscripts differ $(P<0.05)$.

${ }^{\mathrm{A}, \mathrm{B}}$ Least squares means within column with different superscripts differ $(P<0.05)$.

${ }^{1}$ Presented mRNA abundance is expressed relative to mRNA abundances of low condition group at $\mathrm{d}-42$.

${ }^{2} A T F 4=$ activating transcription factor $4 ; D D I T 3=$ DNA-damage-inducible transcript $3 ; F G F 21=$ fibroblast growth factor $21 ; H S P A 5=$ heat shock 70-kDa protein $5 ; X B P 1=\mathrm{X}$-box binding protein 1.

${ }^{3}$ Treatment: high BCS groups ( $\mathrm{HC} /$ Control, $\mathrm{n}=7 ; \mathrm{HC} / \mathrm{MO}, \mathrm{n}=8 ; \mathrm{HC} / \mathrm{EO}, \mathrm{n}=8$ ) received a concentrate proportion of $60 \%$ (HC); low $\mathrm{BCS}$ cows $(\mathrm{n}=7)$ were fed a concentrate proportion of $20 \%(\mathrm{LC})$ in the prepartal diet. Postcalving, the concentrate proportion in the diet was increased from 30 to $50 \%$ within $2 \mathrm{wk}$ in LC group and $3 \mathrm{wk}$ in $\mathrm{HC}$ groups. HC/MO was administered a monensin (MO) controlled-release capsule (Kexxtone, Elanco, Bad Homburg, Germany) at d -21, HC/EO received $1 \mathrm{~g} / \mathrm{d}$ of a blend of essential oils (EO; Crina Ruminants, DSM, Basel, Switzerland) from $\mathrm{d}-21$ until $\mathrm{d}+56$ relative to calving.
} 
phase proteins, such as haptoglobin or serum amyloid A, after experimental induction of SARA (Gozho et al., 2005, 2006, 2007; Khafipour et al., 2009). We cannot give evidence for a similar association between ruminal LPS and acute phase response in this study, as ruminal LPS was not determined before the peak of serum haptoglobin concentration on $\mathrm{d} 7$.

The great time-dependent variance of liver mRNA expression indicates that the transition period of the dairy cow is generally associated with ER stress, which agrees with the observations of Gessner et al. (2014). Indeed, the gene expression of HSPA5 encoding for immunoglobulin heavy-chain binding protein, a master regulator of the UPR (Cnop et al., 2012), was increased after calving. Fibroblast growth factor 21 was reported to play a regulatory role in fasting states controlling lipid homeostasis and ketogenesis (Badman et al., 2007). We found no correlation with serum BHB in our study, but a positive correlation with liver lipid content $(\mathrm{r}=0.23, P=0.05$; Drong et al., 2016a).

Nuclear factor E2-related factor 2 is a transcription factor activated by changes in the redox state of the cell and, subsequently, upregulates genes for antioxidant and cytoprotective enzymes (Baird and Dinkova-Kostova, 2011). Gessner et al. (2013) showed that Nrf2 target genes are upregulated during the transition period and hypothesized that this might prevent liver damage by the increased generation of reactive oxygen species at that time. This might originate from an inflammatory condition or the increased energy provision via the electron transport chain.

The Nrf2 target genes GPX3 and CAT encode for proteins that belong to the major classes of antioxidative enzymes (Sies, 1997). Both showed high variation, emphasizing the occurrence of oxidative stress at calving in the present trial. The mRNA abundance of GPX3, in particular, increased from antepartal values to $\mathrm{d} 7$ in both $\mathrm{LC}$ and $\mathrm{HC}$ cows, although the gene expression level was about 3 times higher in LC than in $\mathrm{HC}$ over the whole trial (Figure 3). In accordance, high-BCS cows were recently reported to have a lower availability of antioxidative mechanisms (O'Boyle et al., 2006). We previously showed that serum fatty acids, which were higher in $\mathrm{HC}$ cows after calving, influenced the reactive oxygen species production in neutrophils (Drong et al., 2016b). Positive correlations between GPX3 and $C A T$ with the master regulator of the UPR HSPA5 $(\mathrm{r}=0.46$ and 0.29 , respectively, $P<0.001$ ) provide evidence for the previously reported link between ER stress and the activation of Nrf2 transcription factor (Cullinan et al., 2003; Cullinan and Diehl, 2006).

Metabolic stress is another trigger for the induction of UPR and the subsequent possible activation of Nrf2 and inflammation (Kharroubi et al., 2004; Ringseis et al., 2015). Accordingly, we found a positive correlation of serum fatty acids (Drong et al., 2016a) with mRNA abundances of the UPR target genes HSPA5 $(\mathrm{r}=0.29$, $P=0.002), X B P 1(\mathrm{r}=0.29, P=0.001)$, and FGF21 ( $\mathrm{r}=0.23, P=0.008)$. Gessner et al. (2013) reported no correlation between Nrf2 target genes and fatty acids and BHB and stated that the negative energy balance might not be the main factor responsible for upregulation of those genes. We can only partly agree, as we found a positive correlation of serum fatty acids and BHB (Drong et al., 2016a) with mRNA abundance of Nrf2 target genes GPX3 $(\mathrm{r}=0.53$ and $0.25, P<$ $0.05)$ and a negative correlation with $C A T(\mathrm{r}=-0.28$ and $-0.19, P<0.05$ ). Serum BHB was additionally positively correlated with mRNA abundance of $N Q O 1$ $(\mathrm{r}=0.18, P>0.05)$. Finally, fatty acids and BHB were positively correlated with mRNA abundances of SAA3 $(\mathrm{r}=0.59$ and $0.39, P<0.001)$ and $H P(\mathrm{r}=$ 0.47 and $0.24, P<0.05)$ and with serum haptoglobin concentration $(\mathrm{r}=0.35$ and $0.22, P<0.001)$, which indicates some connection between degree of postpartal fat mobilization and inflammation.

\section{Effect of Monensin and Essential Oils in HC Cows}

We studied the effects of supplementing monensin or essential oils on the inflammatory response that might be traced back to changes in rumen microbiota leading to a ruminal LPS accumulation. Although we only determined free ruminal LPS concentration after parturition, results indicate that the LPS concentration was higher after monensin supplementation compared with the $\mathrm{HC}$ control group. It is important to note that the number of animals used for the ruminal LPS determination in this study ( $\mathrm{n}=4$ per group) is rather small. Together with the large individual differences between the animals and high measurement variations, results should be interpreted cautiously. Nevertheless, results might underline the proposed mode of action of monensin in the rumen. Monensin acts as a vehicle for transporting ions across biological membranes (Pressman and Fahim, 1982) and leads to a growth inhibition of gram-positive bacteria. Gram-negative bacteria possess a natural protective barrier against monensin, as the outer membrane is impermeable for hydrophobic substances and molecules with size of ionophores (Russell and Strobel, 1989). Therefore, monensin leads to a shift of the ruminal bacterial population toward gram-negative species accompanied by a higher propionate production. Propionate is reported to be the main precursor of hepatic gluconeogenesis (Seal and Reynolds, 1993), and thus attributed as a main etiological factor in the antiketogenic effect of monensin, as found 
in the present study (Duffield et al., 2008; Drong et al., 2016a). As previously described, LPS is part of the outer membrane of gram-negative bacteria and released at bacterial cell death and lysis, which might be increased in times of low ruminal pH (Nagaraja et al., 1978; Rietschel et al., 1994). Most LPS is produced by rapidly growing gram-negative bacteria, as the rapid growth phase of bacteria is accompanied by excessive bacterial lysis (Wells and Russell, 1996). The unaltered ruminal LPS concentration in $\mathrm{HC} / \mathrm{EO}$ in comparison to the $\mathrm{HC}$ group agrees with our previous results, indicating that essential oils did not affect the ruminal bacterial population, leading to a higher acetate-to-propionate ratio, as shown for monensin (Drong et al., 2016a).

Ruminal LPS was reported to participate in the induction of ER stress that, in ,turn is involved in the development of liver-associated diseases of the cow, as it activates lipogenesis and limits lipoprotein formation and secretion (Zhang et al., 2014; Ringseis et al., 2015). However, we found no correlation between ruminal LPS concentration and gene expression or liver lipid content (Drong et al., 2016a). X-box binding protein 1 is a transcription factor that is translated after unconventional splicing of $X B P 1 \mathrm{mRNA}$ when ER stress is induced and upregulates chaperons, lipid synthesis, and degradation of misfolded proteins (Ron and Walter, 2007). The greater mRNA expression in HC/MO than in $\mathrm{HC} / \mathrm{EO}$ cows might indicate a more distinct UPR in monensin-treated animals, either due to more ER stress or a better ability to induce the UPR.

The expression of GPX3 encoding for antioxidative enzymes was higher the in liver of LC than in $\mathrm{HC} /$ EO cows, which might indicate either more oxidative stress or an improved ability of liver to cope with these conditions. The HC/MO cows showed a nearly 100 -fold increase in GPX3 gene abundance on d 7 in comparison to $\mathrm{d}-42$ relative to calving (Figure 3 ). The observed distinct association of the GPX3 mRNA abundance with serum and hepatic gene expression of haptoglobin ( $\mathrm{r}=0.82$ and 0.80 , respectively, $P<0.001)$ might also contribute to the protection of tissues from oxidative damages. Haptoglobin exerts antioxidative functions, as it binds free hemoglobin and NO (Dobryszycka, 1997). Accordingly, a trend for a greater HP mRNA abundance in $\mathrm{LC}$ than in $\mathrm{HC} / \mathrm{EO}$ group was found and the course of the correlating serum haptoglobin concentration (Figure 1) indicates a similar issue. An analogous course was also apparent for the $\mathrm{HC} / \mathrm{MO}$ group, with the most prominent increase in $H P$ mRNA abundance in comparison to antepartal values on $\mathrm{d} 7$ (290 fold, Figure 3).

A hepatic and systemic inflammatory response was reported to be a trigger of and a possible consequence of ER stress (Ringseis et al., 2015). In fact, the mRNA abundance of $H S P A 5$ was positively correlated with gene expression of CRP, SAA3, and HP $(\mathrm{r}=0.41,0.39$, and 0.55 , respectively, $P<0.001)$ and serum haptoglobin $(\mathrm{r}=0.50, P<0.001)$.

On the one hand, evidence shows that increased haptoglobin concentrations could cause immunosuppression, as shown for a diminished lymphocyte proliferation to mitogen stimulus and an impaired lymphocyte blastogenesis in calves (Murata and Miyamoto, 1993). Analogous to that, serum haptoglobin was negatively correlated with unstimulated rhodamine $123+$ population $(\mathrm{r}=-0.19 ; P=0.003)$, describing the basal reactive oxygen species generation of neutrophils and the stimulation index of peripheral blood mononuclear cells ( $\mathrm{r}=-0.13 P=0.047$ ) of the present trial (Drong et al., 2016b). On the other hand, the biological functions of haptoglobin include, besides the previously described antioxidative property, anti-inflammatory and immunomodulatory effects (Ceciliani et al., 2012). Thus, a higher haptoglobin response to inflammatory stimuli after calving might indicate a more optimal response and, hence, an improved immune function, as suggested by Crawford et al. (2005). Those authors examined the effects of a monensin CRC administered 3 wk antepartum in 1,010 dairy cows and heifers and reported a higher haptoglobin response in clinically unhealthy heifers in the first week of lactation after monensin supplementation. Furthermore, monensin increased postpartal concentrations of plasma ceruloplasmin, an acute phase protein that is important in controlling oxidative challenge from free radicals (Stephenson et al., 1997).

Endoplasmatic reticulum stress might be a possible explanation why comparable metabolic conditions do not lead to consistent liver-associated diseases, such as ketosis and fatty liver syndrome, in all cows, as it might be a contributing factor to the liver's capacity to cope with inflammatory and metabolic challenges in early lactation (Zhang et al., 2014; Ringseis et al., 2015). There is more research necessary to answer the question if the increased hepatic gene expression of UPR target genes, antioxidative genes, and acute phase protein genes and high serum haptoglobin concentrations are interrelated with each other. Overall, the results of our study gave no clear evidence for an effect of essential oils in the rumen (Drong et al., 2016a) and systemically in the animal, which might be due to the supplemented dose and blend. If the prominent activation of antioxidative mechanisms in $\mathrm{HC} / \mathrm{MO}$ group contributes to the lowered ketone body formation and liver lipid accumulation in comparison to the high-body condition counterparts, despite similar high fatty acid concentrations (Drong et al., 2016a), needs to be further clarified. 


\section{CONCLUSIONS}

The present study confirms the idea of the occurrence of inflammatory-like phenomena in dairy cows around calving, as seen in increasing serum haptoglobin concentrations, kynurenine-to-tryptophan ratio, and alterations in the hepatic mRNA expression of acute phase proteins. The ruminal LPS concentration was independent of antepartal body condition, concentrate feeding management, and essential oils supplementation, but it seemed to be higher after monensin supplementation. We found no evidence for an association between ruminal LPS concentration and any of the evaluated inflammatory markers or mRNA gene expression of the target genes investigated in the present trial. Our data indicate the occurrence of ER stress during the transition period was independent of antepartal body condition and concentrate feeding, and was most pronounced in $\mathrm{HC} / \mathrm{MO}$ animals. The increased mRNA abundance of Nrf2 target genes encoding for proteins with antioxidative properties and of haptoglobin, which also exerts antioxidative effects, might indicate a measure to protect the liver from oxidative stress around calving, and was most prominent in cows with a low antepartal BCS and concentrate feeding. The HC/MO group also showed a similar activation of antioxidative mechanisms in the liver, which raises the question whether this may contribute to the antiketogenic effect of monensin in cows with a high body condition.

\section{REFERENCES}

Badman, M. K., P. Pissios, A. R. Kennedy, G. Koukos, J. S. Flier, and E. Maratos-Flier. 2007. Hepatic fibroblast growth factor 21 is regulated by PPAR $\alpha$ and is a key mediator of hepatic lipid metabolism in ketotic states. Cell Metab. 5:426-437. https://doi. org/10.1016/j.cmet.2007.05.002.

Baird, L., and A. T. Dinkova-Kostova. 2011. The cytoprotective role of the Keap1-Nrf2 pathway. Arch. Toxicol. 85:241-272. https://doi. org/10.1007/s00204-011-0674-5.

Bertoni, G., E. Trevisi, X. Han, and M. Bionaz. 2008. Effects of inflammatory conditions on liver activity in puerperium period and consequences for performance in dairy cows. J. Dairy Sci. 91:33003310. https://doi.org/10.3168/jds.2008-0995.

Bionaz, M., E. Trevisi, L. Calamari, F. Librandi, A. Ferrari, and G. Bertoni. 2007. Plasma paraoxonase, health, inflammatory conditions, and liver function in transition dairy cows. J. Dairy Sci. 90:1740-1750. https://doi.org/10.3168/jds.2006-445.

Bobe, G., J. Young, and D. Beitz. 2004. Invited review: Pathology, etiology, prevention, and treatment of fatty liver in dairy cows. J. Dairy Sci. 87:3105-3124. https://doi.org/10.3168/jds.S00220302(04)73446-3.

Bradford, B. J., K. Yuan, J. Farney, L. Mamedova, and A. Carpenter. 2015. Invited review: Inflammation during the transition to lactation: New adventures with an old flame. J. Dairy Sci. 98:66316650. https://doi.org/10.3168/jds.2015-9683.

Ceciliani, F., J. J. Ceron, P. D. Eckersall, and H. Sauerwein. 2012. Acute phase proteins in ruminants. J. Proteomics 75:4207-4231. https://doi.org/10.1016/j.jprot.2012.04.004.
Cnop, M., F. Foufelle, and L. A. Velloso. 2012. Endoplasmic reticulum stress, obesity and diabetes. Trends Mol. Med. 18:59-68. https:// doi.org/10.1016/j.molmed.2011.07.010.

Crawford, R. G., K. E. Leslie, R. Bagg, C. P. Dick, and T. F. Duffield. 2005. The impact of controlled release capsules of monensin on postcalving haptoglobin concentrations in dairy cattle. Can. J. Vet. Res. 69:208-214.

Cullinan, S. B., and J. A. Diehl. 2004. PERK-dependent activation of Nrf2 contributes to redox homeostasis and cell survival following endoplasmic reticulum stress. J. Biol. Chem. 279:20108-20117. https://doi.org/10.1074/jbc.M314219200.

Cullinan, S. B., and J. A. Diehl. 2006. Coordination of ER and oxidative stress signaling: the PERK/Nrf2 signaling pathway. Int. J. Biochem. Cell Biol. 38:317-332. https://doi.org/10.1016/j. biocel.2005.09.018

Cullinan, S. B., D. Zhang, M. Hannink, E. Arvisais, R. J. Kaufman, and J. A. Diehl. 2003. Nrf2 is a direct PERK substrate and effector of PERK-dependent cell survival. Mol. Cell. Biol. 23:7198-7209. https://doi.org/10.1128/MCB.23.20.7198-7209.2003.

de Jong, W. H. A., R. Smit, S. J. L. Bakker, E. G. E. de Vries, and I. P. Kema. 2009. Plasma tryptophan, kynurenine and 3-hydroxykynurenine measurement using automated on-line solid-phase extraction HPLC-tandem mass spectrometry. J. Chromatogr. B Analyt. Technol. Biomed. Life Sci. 877:603-609. https://doi.org/10.1016/j. jchromb.2009.01.015.

Dobryszycka, W. 1997. Biological functions of haptoglobin-new pieces to an old puzzle. Eur. J. Clin. Chem. Clin. Biochem. 35:647-654.

Drong, C., U. Meyer, D. von Soosten, J. Frahm, J. Rehage, G. Breves, and S. Dänicke. 2016a. Effect of monensin and essential oils on performance and energy metabolism of transition dairy cows. J. Anim. Physiol. Anim. Nutr. (Berl.) 100:537-551. https://doi. org/10.1111/jpn.12401

Drong, C., U. Meyer, D. von Soosten, J. Frahm, J. Rehage, H. Schirrmeier, M. Beer, and S. Dänicke. 2016b. Effects of monensin and essential oils on immunological, haematological and biochemical parameters of cows during the transition period. J. Anim. Physiol. Anim. Nutr. (Berl.) https://doi.org/10.1111/jpn.12494.

Duffield, T. 2000. Subclinical ketosis in lactating dairy cattle. Vet. Clin. North Am. Food Anim. Pract. 16:231-253. https://doi. org/10.1016/S0749-0720(15)30103-1.

Duffield, T. F., A. Rabiee, and I. Lean. 2008. A meta-analysis of the impact of monensin in lactating dairy cattle. Part 1. Metabolic effects. J. Dairy Sci. 91:1334-1346. https://doi.org/10.3168/ jds.2007-0607.

Edmonson, A. J., I. J. Lean, L. D. Weaver, T. Farver, and G. Webster. 1989. A body condition scoring chart for Holstein dairy cows. J. Dairy Sci. 72:68-78.

Edris, A. E. 2007. Pharmaceutical and therapeutic potentials of essential oils and their individual volatile constituents: A review. Phytother. Res. 21:308-323. https://doi.org/10.1002/ptr.2072.

Fu, S., S. M. Watkins, and G. S. Hotamisligil. 2012. The role of endoplasmic reticulum in hepatic lipid homeostasis and stress signaling. Cell Metab. 15:623-634. https://doi.org/10.1016/j. cmet.2012.03.007.

Gessner, D. K., G. Schlegel, J. Keller, F. J. Schwarz, R. Ringseis, and K. Eder. 2013. Expression of target genes of nuclear factor E2related factor 2 in the liver of dairy cows in the transition period and at different stages of lactation. J. Dairy Sci. 96:1038-1043. https://doi.org/10.3168/jds.2012-5967.

Gessner, D. K., G. Schlegel, R. Ringseis, F. J. Schwarz, and K. Eder. 2014. Up-regulation of endoplasmic reticulum stress induced genes of the unfolded protein response in the liver of periparturient dairy cows. BMC Vet. Res. 10:46. https://doi.org/10.1186/1746-6148$10-46$.

GfE. 1991. Leitlinien für die Bestimmung der Verdaulichkeit von Rohnährstoffen an Wiederkäuern. J. Anim. Physiol. Anim. Nutr. (Berl.) 65:229-234.

GfE. 2001. Empfehlung zur Energie- und Nährstoffversorgung von Milchkühen und Aufzuchtrindern. DLG-Verlags GmbH, Frankfurt am Main, Germany. 
GfE. 2008. New equations for predicting metabolisable energy of grass and maize products for ruminants. Proc. Soc. Nutr. Physiol. $17: 191-198$.

Gozho, G. N., D. O. Krause, and J. C. Plaizier. 2006. Rumen lipopolysaccharide and inflammation during grain adaptation and subacute ruminal acidosis in steers. J. Dairy Sci. 89:4404-4413. https://doi.org/10.3168/jds.S0022-0302(06)72487-0.

Gozho, G. N., D. O. Krause, and J. C. Plaizier. 2007. Ruminal lipopolysaccharide concentration and inflammatory response during grain-induced subacute ruminal acidosis in dairy cows. J. Dairy Sci. 90:856-866. https://doi.org/10.3168/jds.S0022-0302(07)71569-2.

Gozho, G. N., J. C. Plaizier, D. O. Krause, A. D. Kennedy, and K. M. Wittenberg. 2005. Subacute ruminal acidosis induces ruminal lipopolysaccharide endotoxin release and triggers an inflammatory response. J. Dairy Sci. 88:1399-1403. https://doi.org/10.3168/jds. S0022-0302(05)72807-1.

Groebner, A. E., K. Schulke, J. C. Schefold, G. Fusch, F. Sinowatz, H. D. Reichenbach, E. Wolf, H. H. Meyer, and S. E. Ulbrich. 2011. Immunological mechanisms to establish embryo tolerance in early bovine pregnancy. Reprod. Fertil. Dev. 23:619-632. https://doi. org/10.1071/RD10230.

Grummer, R. R. 1995. Impact of changes in organic nutrient metabolism on feeding the transition dairy cow. J. Anim. Sci. 73:28202833.

Hayaishi, O. 1976. Properties and function of indoleamine 2, 3-dioxygenase. J. Biochem. 79:13P-21P.

Hiss, S., M. Mielenz, R. M. Bruckmaier, and H. Sauerwein. 2004 Haptoglobin concentrations in blood and milk after endotoxin challenge and quantification of mammary $\mathrm{Hp}$ mRNA expression. J. Dairy Sci. 87:3778-3784. https://doi.org/10.3168/jds.S00220302(04)73516-X.

Littell, R., P. Henry, and C. Ammerman. 1998. Statistical analysis of repeated measures data using SAS procedures. J. Anim. Sci 76:1216-1231

Khafipour, E., D. O. Krause, and J. C. Plaizier. 2009. A grain-based subacute ruminal acidosis challenge causes translocation of lipopolysaccharide and triggers inflammation. J. Dairy Sci. 92:10601070. https://doi.org/10.3168/jds.2008-1389.

Kharroubi, I., L. Ladrière, A. K. Cardozo, Z. Dogusan, M. Cnop, and D. L. Eizirik. 2004. Free fatty acids and cytokines induce pancreatic $\beta$-cell apoptosis by different mechanisms: Role of nuclear factor- $\mathrm{B}$ and endoplasmic reticulum stress. Endocrinology 145:5087-5096. https://doi.org/10.1210/en.2004-0478.

Mao, S. Y., R. Y. Zhang, D. S. Wang, and W. Y. Zhu. 2013. Impact of subacute ruminal acidosis (SARA) adaptation on rumen microbiota in dairy cattle using pyrosequencing. Anaerobe 24:12-19. https://doi.org/10.1016/j.anaerobe.2013.08.003.

McIntosh, F., P. Williams, R. Losa, R. Wallace, D. Beever, and C. Newbold. 2003. Effects of essential oils on ruminal microorganisms and their protein metabolism. Appl. Environ. Microbiol. 69:5011-5014.

Murata, H., and T. Miyamoto. 1993. Bovine haptoglobin as a possible immunomodulator in the sera of transported calves. Br. Vet. J. 149:277-283. https://doi.org/10.1016/S0007-1935(05)80173-3.

Nagaraja, T. G., E. E. Bartley, L. R. Fina, and H. D. Anthony. 1978. Relationship of rumen gram-negative bacteria and free endotoxin to lactic acidosis in cattle. J. Anim. Sci. 47:1329-1337.

O'Boyle, N., C. M. Corl, J. C. Gandy, and L. M. Sordillo. 2006. Relationship of body condition score and oxidant stress to tumor necrosis factor expression in dairy cattle. Vet. Immunol. Immunopathol. 113:297-304. https://doi.org/10.1016/j.vetimm.2006.05.013.

Penner, G. B., K. A. Beauchemin, and T. Mutsvangwa. 2007. Severity of ruminal acidosis in primiparous Holstein cows during the periparturient period. J. Dairy Sci. 90:365-375. https://doi. org/10.3168/jds.S0022-0302(07)72638-3.

Plaizier, J. C., D. O. Krause, G. N. Gozho, and B. W. McBride. 2008. Subacute ruminal acidosis in dairy cows: The physiological causes, incidence and consequences. Vet. J. 176:21-31. https://doi. org/10.1016/j.tvjl.2007.12.016.
Pressman, B. C., and M. Fahim. 1982. Pharmacology and toxicology of the monovalent carboxylic ionophores. Annu. Rev. Pharmacol. Toxicol. 22:465-490. https://doi.org/10.1146/annurev. pa.22.040182.002341

Rietschel, E. T., T. Kirikae, F. U. Schade, U. Mamat, G. Schmidt, H. Loppnow, A. J. Ulmer, U. Zähringer, U. Seydel, and F. Di Padova. 1994. Bacterial endotoxin: Molecular relationships of structure to activity and function. FASEB J. 8:217-225.

Ringseis, R., D. K. Gessner, and K. Eder. 2015. Molecular insights into the mechanisms of liver-associated diseases in early-lactating dairy cows: Hypothetical role of endoplasmic reticulum stress. J. Anim. Physiol. Anim. Nutr. (Berl.) 99:626-645. https://doi.org/10.1111/ jpn.12263.

Ron, D., and P. Walter. 2007. Signal integration in the endoplasmatic reticulum unfolded protein response. Nat. Rev. Mol. Cell Biol. $8: 519-529$.

Russell, J. B., and H. Strobel. 1989. Effect of ionophores on ruminal fermentation. Appl. Environ. Microbiol. 55:1-6.

Schröcksnadel, H., G. Baier-Bitterlich, O. Dapunt, H. Wachter, and D. Fuchs. 1996. Decreased plasma tryptophan in pregnancy. Obstet. Gynecol. 88:47-50.

Schröcksnadel, K., B. Widner, A. Bergant, G. Neurauter, H. Schröcksnadel, and D. Fuchs. 2003. Tryptophan degradation during and after gestation. Adv. Exp. Med. Biol. 527:77-83.

Schulz, K., J. Frahm, U. Meyer, S. Kersten, D. Reiche, J. Rehage, and S. Dänicke. 2014. Effects of prepartal body condition score and peripartal energy supply of dairy cows on postpartal lipolysis, energy balance and ketogenesis: An animal model to investigate subclinical ketosis. J. Dairy Res. 81:257-266. https://doi.org/10.1017/ S0022029914000107.

Seal, C. J., and C. Reynolds. 1993. Nutritional implications of gastrointestinal and liver metabolism in ruminants. Nutr. Res. Rev. 6:185-208. https://doi.org/10.1079/NRR19930012.

Sies, H. 1997. Oxidative stress: Oxidants and antioxidants. Exp. Physiol. 82:291-295. https://doi.org/10.1113/expphysiol.1997.sp004024.

Stephenson, K. A., I. J. Lean, M. L. Hyde, M. A. Curtis, J. K. Garvin, and L. B. Lowe. 1997. Effects of monensin on the metabolism of periparturient dairy cows. J. Dairy Sci. 80:830-837. https://doi. org/10.3168/jds.S0022-0302(97)76004-1.

Trevisi, E., M. Amadori, S. Cogrossi, E. Razzuoli, and G. Bertoni 2012. Metabolic stress and inflammatory response in high-yielding, periparturient dairy cows. Res. Vet. Sci. 93:695-704. https://doi org/10.1016/j.rvsc.2011.11.008.

Trey, J. E., and I. Kushner. 1995. The acute phase response and the hematopoietic system: The role of cytokines. Crit. Rev. Oncol Hematol. 21:1-18. https://doi.org/10.1016/1040-8428(94)00141-3.

Vandesompele, J., K. De Preter, F. Pattyn, B. Poppe, N. Van Roy A. De Paepe, and F. Speleman. 2002. Accurate normalization of real-time quantitative RT-PCR data by geometric averaging of multiple internal control genes. Genome Biol. 3:research0034.

Wells, J. E., and J. B. Russell. 1996. The effect of growth and starvation on the lysis of the ruminal cellulolytic bacterium Fibrobacter succinogenes. Appl. Environ. Microbiol. 62:1342-1346.

Werner, E. R., G. Bitterlich, D. Fuchs, A. Hauser, G. Reibnegger, G. Szabo, M. P. Dierich, and H. Wachter. 1987. Human macrophages degrade tryptophan upon induction by interferon-gamma. Life Sci. 41:273-280. https://doi.org/10.1016/0024-3205(87)90149-4.

Zebeli, Q., K. Ghareeb, E. Humer, B. U. Metzler-Zebeli, and U. Besenfelder. 2015. Nutrition, rumen health and inflammation in the transition period and their role on overall health and fertility in dairy cows. Res. Vet. Sci. 103:126-136. https://doi.org/10.1016/j. rvsc.2015.09.020.

Zhang, K., and R. J. Kaufmann. 2008. From endoplasmic-reticulum stress to the inflammatory response. Nature 454:455-462. https:// doi.org/10.1038/nature07203.

Zhang, X.-Q., C.-F. Xu, C.-H. Yu, W.-X. Chen, and Y.-M. Li. 2014. Role of endoplasmic reticulum stress in the pathogenesis of nonalcoholic fatty liver disease. World J. Gastroenterol. 20:1768-1776. https://doi.org/10.3748/wjg.v20.i7.1768. 